7. Reprod. Fert. (1970) 22, 151-153

\title{
PRELIMINARY OBSERVATIONS IN THE RABBIT ON THE ANTI-OVULATORY ACTIVITY PRESENT IN TAXUS BACCATA LINN. LEAVES
}

\author{
R. R. GHAUDHURY, S. K. SAKSENA AND S. K. GARG \\ Department of Pharmacology, Postgraduate Institute \\ of Medical Education and Research, Chandigarh, India
}

(Received 10th November 1969, revised 6th Fanuary 1970)

Taxus baccata Linn., a tree which grows abundantly in India, has been reported to possess an antifertility effect (Kirtikar \& Basu, 1935; Chopra, Nayar \& Chopra, 1956; Chopra, Chopra, Handa \& Kapoor, 1958; Chaudhury, 1966). Khanna, Garg, Vohora, Walia \& Chaudhury (1969) recently reported that anti-implantation activity is present in the leaves. Possible anti-ovulatory activity of different extracts of leaves of Taxus baccata has been screened on fifty-eight, adult, non-pregnant rabbits, each weighing between 1.5 and $2.0 \mathrm{~kg}$. The rabbits were obtained from a local source and housed in independent cages for at least 3 weeks before use.

The air-dried, powdered leaves of Taxus baccata were successively extracted with petroleum ether (b.p. 60 to $80^{\circ} \mathrm{C}$ ), alcohol (95\%) and distilled water and the extracts were administered as a suspension with gum acacia, by a soft rubber catheter, at different intervals before induction of ovulation. Ovulation was induced by injecting copper acetate intravenously $(4.0 \mathrm{mg} / \mathrm{kg})$, a method which has been standardized in this laboratory (Khanna \& Chaudhury, 1968). Earlier investigators have used induction of ovulation by cupric gluconate (Suzuki \& Bialy, 1964) as a method for testing anti-ovulatory substances. To assess ovulation, laparotomies were carried out on the rabbit $48 \mathrm{hr}$ after the copper acetate injection and the bleeding points on each ovary were noted.

The results of the experiments are shown in Table 1 . The results indicate that, when administered at a dose of $200 \mathrm{mg} / \mathrm{kg}$ for 2 days, the petroleum ether and alcoholic extracts of the leaves of Taxus baccata did not prevent ovulation to any marked degree. When the aqueous extract of the leaves was administered at a dose of $400 \mathrm{mg} / \mathrm{kg}$ for 2 days, maximal anti-ovulatory activity was detected $(100 \%)$. When the same dose of the aqueous extract was administered for only 1 day, there was no anti-ovulatory activity. Activity was also detected when doses of 200 and $250 \mathrm{mg} / \mathrm{kg}$ were administered for 2 to 3 days before induction of ovulation. When the average numbers of bleeding points (ovulation points) in the different groups of animals were compared, it appeared that there were fewer in rabbits when Taxus baccata had been administered at a dose of $200 \mathrm{mg} / \mathrm{kg}$ for 3 days (1.00), $250 \mathrm{mg} / \mathrm{kg}$ for 2 days $(1 \cdot 60)$, and $400 \mathrm{mg} / \mathrm{kg}$ for 1 day $(1 \cdot 80)$. However, bleeding points were present after administration of copper acetate in these animals while there were no bleeding points seen in ten 


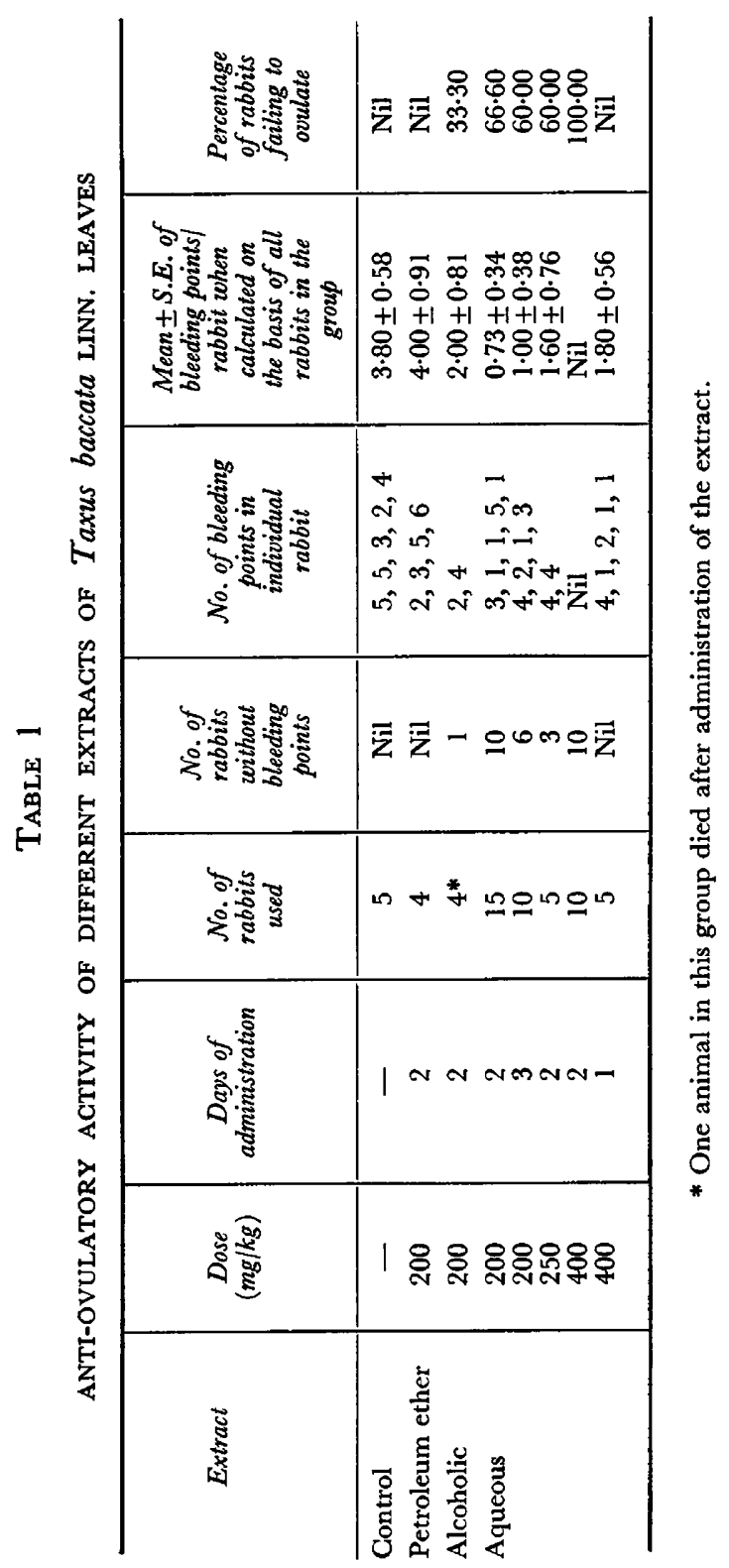


rabbits when Taxus baccata had been administered at a dose of $400 \mathrm{mg} / \mathrm{kg}$ for 2 days. In control rabbits, which were given the vehicle alone, bleeding points were always seen $(3 \cdot 80)$.

The results indicated that the aqueous extract of Taxus baccata possesses anti-ovulatory activity. Further chemical and pharmacological investigations are being conducted with this extract.

The work was sponsored by the Indian Council of Medical Research, New Delhi. The technical help of Mr. J. K. Chhabra is acknowledged.

\section{REFERENCES}

Chaudhury, R. R. (1966) Plants with possible antifertility activity. Ind. Council Med. Res., New Delhi. Chopra, R. N., Ghopra, I. G., Handa, K. L. \& Kapoor, L. D. (1958) Indigenous drugs of India, 2nd edn. U. N. Dhur \& Sons Pvt Ltd, Calcutta.

ChOpra, R. N., NAYAR, S. L. \& Chopra, I. C. (1956) Glossary of Indian medicinal plants. Council of Sci. Ind. Res., New Delhi.

Khanna, U. \& Chaudhury, R. R. (1968) Rapid screening of possible anti-ovulatory substances, using copper induced ovulation. Indian F. Pharm. 30, 148.

Khanna, U., Garg, S. K., Vohora, S. B., Walia, H. B. \& Ghaudhury, R. R. (1969) An antifertility screening of plants. II. Effect of six indigenous plants on early pregnancy in albino rats. Indian 7. med. Res. 57, 237

KIRTiKar, K. R. \& BAsU, B. D. (1935) Indian medicinal plants. Lalit Mohan Basu, Allahabad.

SUZUKI, M. \& BiALY, G. (1964) Studies on copper-induced ovulation in rabbit. Endocrinology, 74, 780. 